\title{
IODP Expedition 325: Great Barrier Reefs Reveals Past Sea-Level, Climate and Environmental Changes Since the Last Ice Age
}

\author{
by Yusuke Yokoyama, Jody M. Webster, Carol Cotterill, Juan Carlos Braga, \\ Luigi Jovane, Heath Mills, Sally Morgan, Atsushi Suzuki, \\ and the IODP Expedition 325 Scientists
}

\begin{abstract}
The timing and courses of deglaciations are key components in understanding the global climate system. Cyclic changes in global climate have occurred, with growth and decay of high latitude ice sheets, for the last two million years. It is believed that these fluctuations are mainly controlled by periodic changes to incoming solar radiation due to the changes in Earth's orbit around the sun. However, not all climate variations can be explained by this process, and there is the growing awareness of the important role of internal climate feedback mechanisms. Understanding the nature of these feedbacks with regard to the timing of abrupt global sea-level and climate changes is of prime importance. The tropical ocean is one of the major components of the feedback system, and hence reconstructions of temporal variations in sea-surface conditions will greatly improve our
\end{abstract}

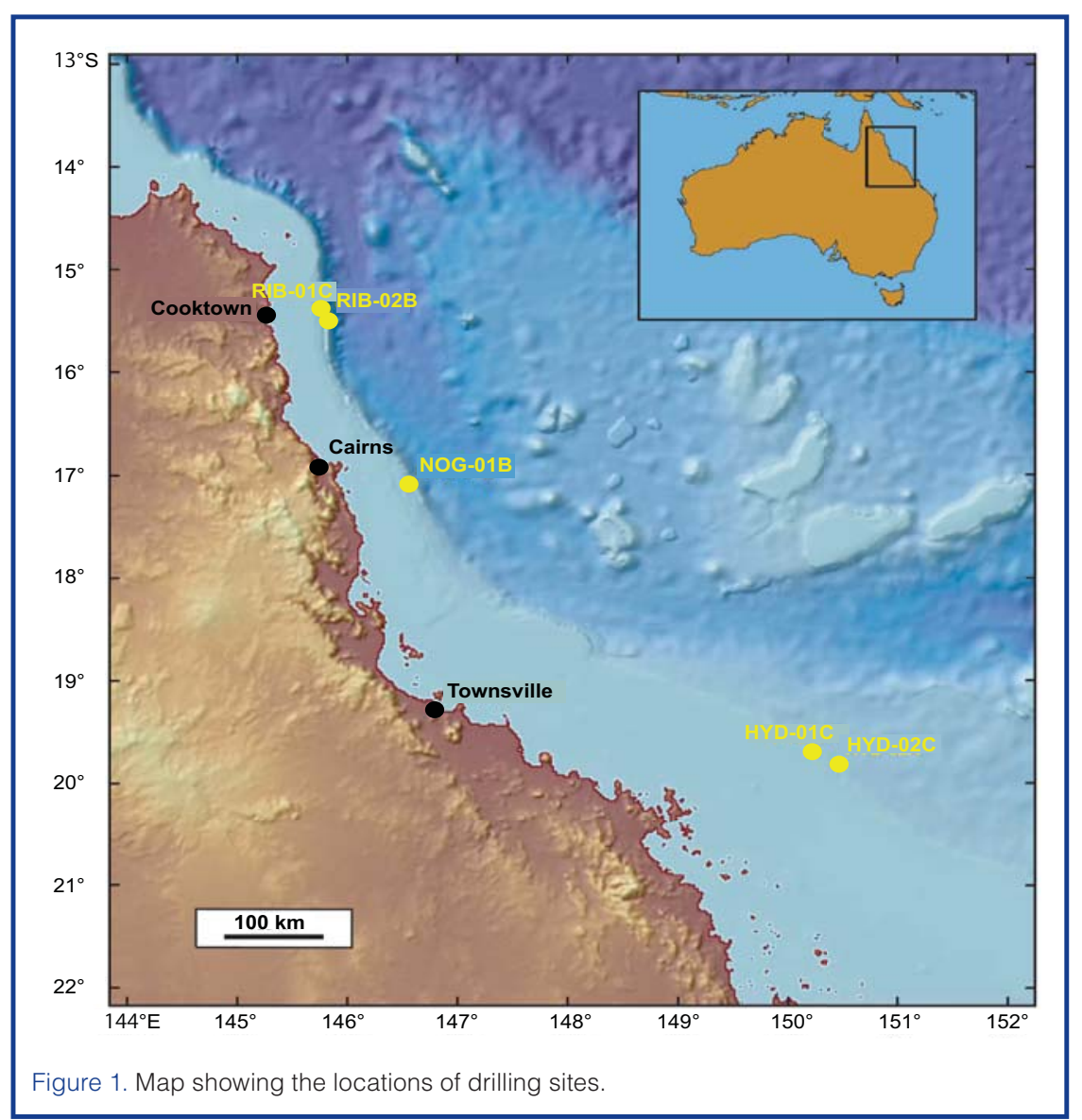

understanding of the climate system. The Integrated Ocean Drilling Program (IODP) Expedition 325 drilled 34 holes across 17 sites in the Great Barrier Reef, Australia to recover fossil coral reef deposits. The main aim of the expedition was to understand the environmental changes that occurred during the last ice age and subsequent deglaciation, and more specifically (1) establish the course of sea-level change, (2) reconstruct the oceanographic conditions, and (3) determine the response of the reef to these changes. We recovered coral reef deposits from water depths down to $126 \mathrm{~m}$ that ranged in age from 9,000 years to older than 30,000 years ago. Given that the interval of the dated materials covers several paleoclimatologically important events, including the Last Glacial Maximum, we expect that ongoing scientific analyses will fulfill the objectives of the expedition.

\section{Introduction and Goals}

The most prominent feature of the current geological era (Quaternary) is the reoccurrence of glacial and interglacial periods. Waxing and waning of the ice sheets across the North American continent as well as northern Eurasia have been recorded. The Antarctic ice sheet, currently the largest ice sheet on Earth, was larger during the glacial times, with an estimated 10-30 m sea-level equivalent stored in global ice volume during the last glacial maximum at about 20 ka (CLIMAP, 1981; Denton and Hughes, 1981; Nakada and Lambeck, 1987; Yokoyama et al., 2001a, 2001b; Ivins and James, 2005). These ice sheets have been a key component in the global climate system due to their locations and size, as well as their ability to release freshwater into the high latitude ocean during melting. Global climate is regulated by ocean circulation, namely thermohaline circulation (THC), which starts in the high latitude oceans where dense and cold deepwater is formed due to the rapid cooling of the saline and warm Gulf Stream. In turn, the input of freshwater from the melting of ice sheets can strongly influence the strength of thermohaline circulation and 


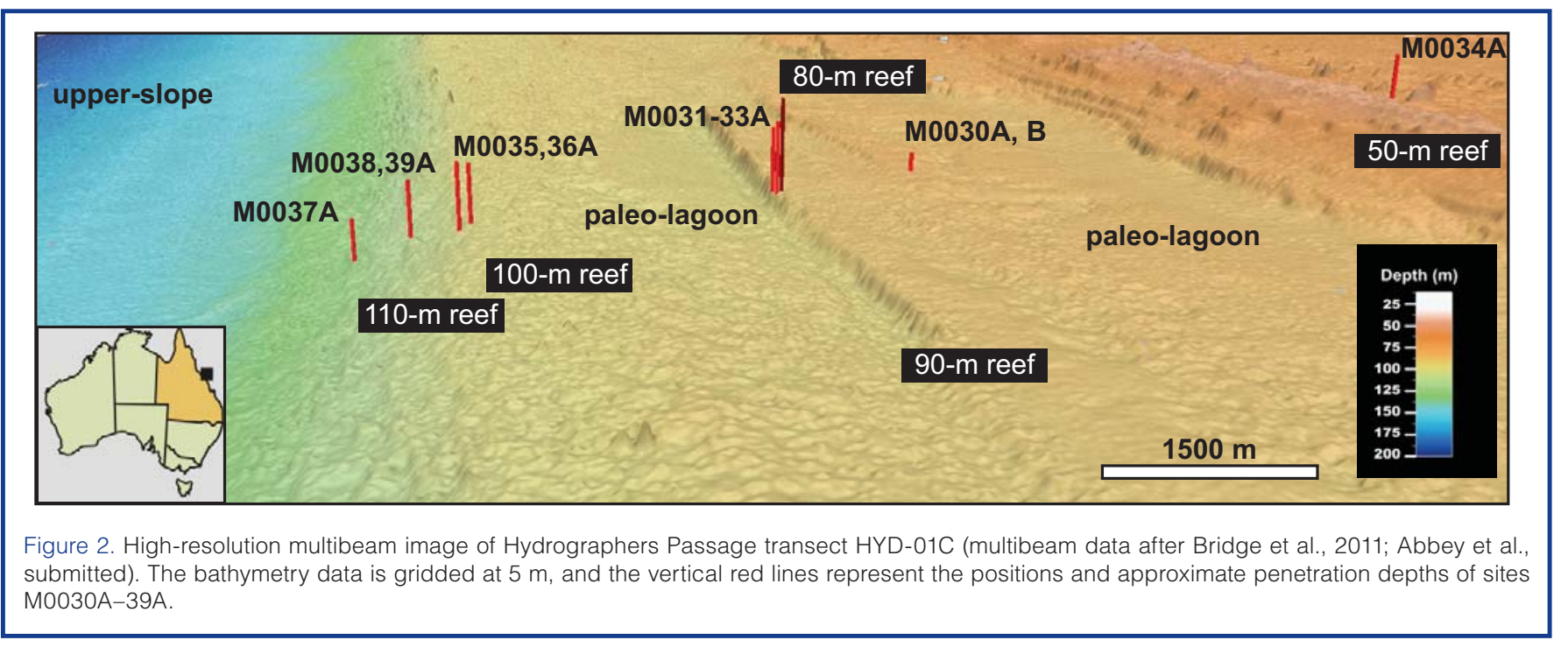

thus drive global climate perturbations (Broecker, 1994; Alley, 1998).

Sophisticated, fully coupled Atmosphere and Ocean General Circulation Models (AOGCM) now predict significant increases in sea surface temperature (SST) by year 2100 due to the release of anthropogenic greenhouse gases and associated atmospheric temperature increase, while ocean acidification, due to higher atmospheric $\mathrm{CO}_{2}$ concentrations and increased solubility in the oceans, may influence large areas of the ocean basins (Solomon et al., 2007). Ice-sheet instability due to increasing temperatures is also anticipated. However, significant uncertainties associated with these model projections remain, and improvement using paleo-data is crucial. Particularly important are the Last Glacial Maximum (LGM: ca. $20 \mathrm{ka}$; Mix et al., 2001) and subsequent deglaciation (starting from $19 \mathrm{ka}$; Yokoyama et al., 2000b; Clark et al., 2009), including Bølling-Allerød, Younger Dryas and Heinrich events (Yokoyama, 2011a, 2011b), as the changes observed from LGM to the present day represent the most recent major global climate reorganization under natural climate forcing (Yokoyama and Esat, 2011).

Corals offer the opportunity to reconstruct past environmental information including sea-level and paleoceanographic changes. Reef building corals live in shallow water, and as they secrete their calcium carbonate skeletons, they encapsulate important oceanographic information such as sea-surface temperatures (SST), sea-surface salinity (SSS), and upwelling intensities. Corals are also the only marine calcifying organisms with a closed uranium series system (Stirling and Andersen, 2009), allowing the precise timing of past environmental events to be established (Edwards et al., 1987; Stirling et al., 1995; Gallup et al., 2002). Coupled with precise radiocarbon dating, these U/Th measurements allow the calibration of radiocarbon chronological data to calendar years (Bard et al., 1990; Edwards et al., 1993; Yokoyama et al., 2000a; Reimer et al., 2004; Fairbanks et al.,
2005; Esat and Yokoyama, 2008). Massive Porites coral grow 1-2 cm annually, and their growth bands allow high temporal resolution (monthly to seasonally) to be made on environment reconstructions (Gagan et al., 1998; Cole et al., 2000; Tudhope et al., 2001; Abram et al., 2008; Felis et al., 2009). Geochemical analyses (stable isotopes, trace elements) of these growth bands allow us to reconstruct seasonal to multi-decadal ENSO signals that can contribute to understanding the natural variability of the climate system.

The Great Barrier Reef (GBR) is the world's largest reef, extending $2000 \mathrm{~km}$ laterally northwest-southeast (Davies et al., 1989). Timing of the reef building is proposed to have started around 0.4-0.5 million years ago (Alexander et al., 2001), which coincides with the Mid Pleistocene Climate transition (MPT) (Hays et al., 1976; Clark et al., 2006) or Marine isotope stage (MIS 11; Webster and Davies, 2003). MIS 11 is known as one of the "warmest" interglacials during the Quaternary, and a period when the 100-ka climate cyclicity between glacial to interglacial states was fully established along with higher sea-level amplitudes. Previous deep drilling investigations through the modern reef confirm that the evolution of the GBR has been strongly influenced by these environmental changes (Webster et al., 2008). Thus, investigating the shelf edge, where the GBR has tracked sea-level and climate change since the last ice age, will provide information about how the reef responded to environmental changes over millennial time scales.

The GBR is ideally situated for sea-level studies, as it is located on a passive margin and is far from former ice sheets (Fig. 1). Therefore, GBR sea-level records can be accurately translated to the ambient ice volume variations due to smaller solid earth deformations caused by glacio-hydro-isostatic adjustments (GIA; Nakada and Lambeck, 1987; Yokoyama et al., 2001a, 2001b; 2006; Lambeck et al., 2002; Milne et al., 2009; Yokoyama and Esat, 2011). After correcting the GIA effect, changes in sea level can be directly translated to ice volumes, meaning that the GBR provides the opportunity to 
remotely monitor the magnitude and timing of ice sheet fluctuations. Located in the southern margin of the Western Pacific Warm Pool (WPWP), the GBR is also well positioned to investigate the role of the tropical Pacific in the climate system. Fossil coral samples from the region can be used to constrain the temporal variations of size of the WPWP and mean temperature with regards to the global climate change.

A diverse suite of fossil coral reef features were observed along the shelf edge of the GBR at 40-130 $\mathrm{m}$ depth during the site survey cruise (Fig. 1). The surface distribution and morphology of these reefs are described in detail elsewhere (Webster et al., 2008; Abbey and Webster, 2011; Abbey et al., submitted; Bridge et al., 2011; Webster et al., 2011). However, we present here a brief summary of the representative morphologic features defining transect HYD-01C on the Mackay shelf in Hydrographer's Passage and their drill sites (Fig. 2) to highlight their potential of recording reef growth back to at least the LGM. At this location a double-fronted barrier reef $200 \mathrm{~m}$ long and $100 \mathrm{~m}$ wide is observed, which is separated by a paleo-lagoon $2 \mathrm{~km}$ wide and as deep as $70 \mathrm{~m}$. The barrier reefs occur at 55-51 m and were sampled by Hole M0034A. A steeply sloping 500-m-wide terrace with a sharp break in slope at $80 \mathrm{~m}$ defines the seaward expression of this feature. Following this, a complex 1-km-wide paleo-lagoon and reef terrace system is observed with prominent reefs at $80 \mathrm{~m}$ and $90 \mathrm{~m}$ that were sampled by M0030A, M0030B, and M0031-33A. Another 700-m-wide paleo-lagoon is observed grading into a complex system of reef pinnacles, terraces, and reefs down to the major
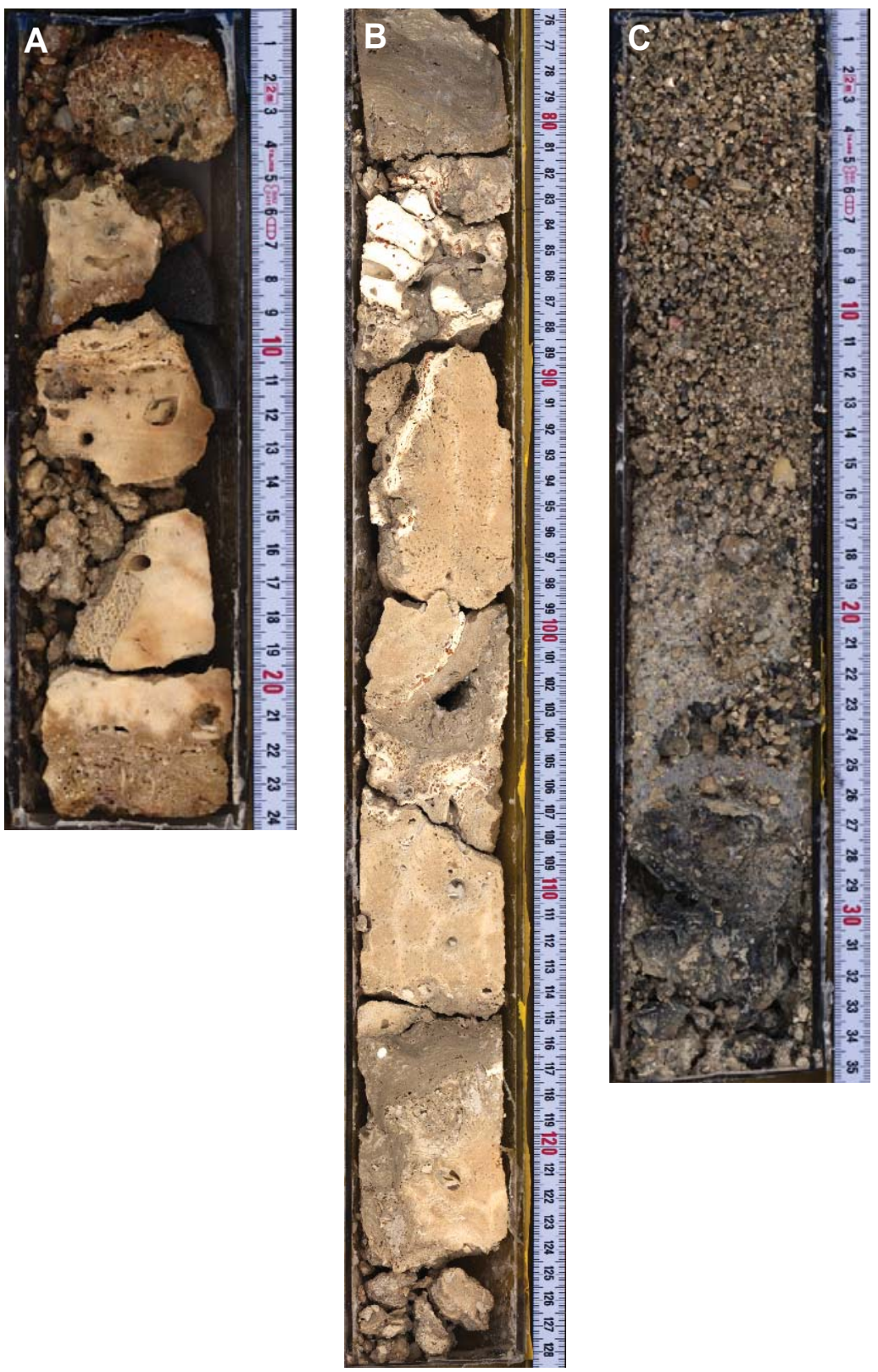

break in slope at $100 \mathrm{~m}$ that defines the shelf edge. Here, M0035A and M0036A sampled the 100-m reef, and seaward of this M0037-39A intersected a series of smaller seaward reef pinnacles and terraces between $110 \mathrm{mbsl}$ (meter below sea level) and $120 \mathrm{mbsl}$, before the seafloor grades into a gentle upper slope characterized by fore-reef slope sediments.

Following the success of the IODP 310 Tahiti drilling expedition (Camoin et al., 2007), detailed reconstructions have emerged of sea level (Deschamps et al., 2009; Thomas et al., 2009; Fujita et al., 2010), paleoclimate (Asami et al., 2009; DeLong et al., 2010; Inoue et al., 2010) and reef respon- ses (Camoin et al., 2010; Abbey et al., submitted; Seard et al., 2011). However, due to the geometry of the flanks of Tahiti, IODP 310 did not recover a full range of the last deglaciation sequence older than $\sim 16,000$ years ago, in particular the LGM fossil reefs (Camoin et al., 2007). Therefore, details of reconstructions of sea level and paleoenvironments since the LGM are yet to be obtained.

The three main scientific objectives of Exp. 325 are as follows:

1) establish the course of sea-level rise during the last deglaciation $(20-10 \mathrm{ka})$ with a particular focus on the interval (>16 ka) not sampled by Exp. 310 


\begin{tabular}{|c|c|c|c|c|c|c|c|c|c|c|c|}
\hline$\frac{\text { T }}{\frac{O}{\sigma}}$ & 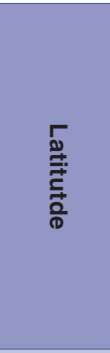 & 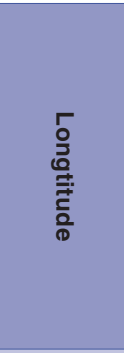 & 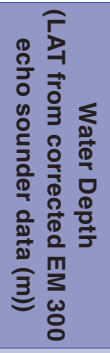 & 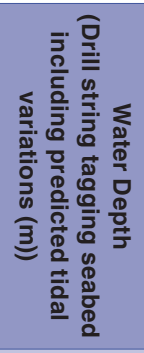 & 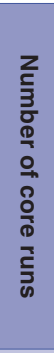 & 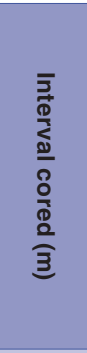 & 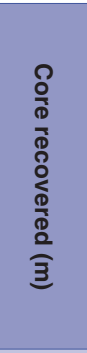 & 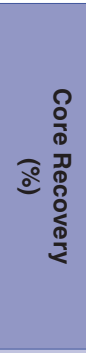 & 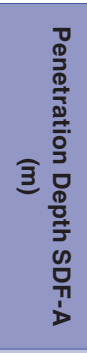 & 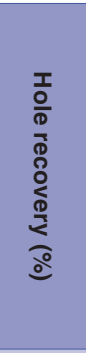 & 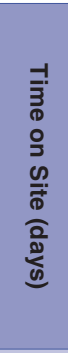 \\
\hline M0030A & 19.6819 & 150.2379 & 83.47 & 85.00 & 2 & 6.00 & 0.24 & 4.00 & 6.00 & 4.00 & 0.85 \\
\hline М0030В & 19.6819 & 150.2379 & 83.47 & 85.00 & 3 & 9.00 & 0.55 & 6.11 & 9.00 & 6.11 & 0.40 \\
\hline M0031A & 19.6790 & 150.2396 & 90.05 & 92.00 & 17 & 43.00 & 5.68 & 13.21 & 43.00 & 13.21 & 2.09 \\
\hline M0032A & 19.6788 & 150.2397 & 91.58 & 93.00 & 20 & 36.70 & 5.99 & 16.32 & 36.70 & 16.32 & 1.15 \\
\hline M0033A & 19.6789 & 150.2399 & 91.32 & 91.50 & 23 & 32.80 & 13.41 & 40.88 & 32.80 & 40.88 & 1.15 \\
\hline M0035A & 19.6726 & 150.2438 & 100.05 & 103.00 & 23 & 29.90 & 12.23 & 40.90 & 29.90 & 40.90 & 2.98 \\
\hline M0036A & 19.6724 & 150.2440 & 103.21 & 103.00 & 22 & 34.00 & 8.91 & 26.21 & 34.00 & 26.21 & 1.77 \\
\hline M0037A & 19.6707 & 150.2463 & 122.29 & 129.17 & 14 & 21.00 & 7.52 & 35.81 & 21.00 & 35.81 & 0.83 \\
\hline M0038A & 19.6716 & 150.2449 & 107.04 & 108.58 & 1 & 1.50 & 0.18 & 12.00 & 1.50 & 12.00 & 0.53 \\
\hline M0039A & 19.6716 & 150.2449 & 107.04 & 108.58 & 21 & 28.40 & 10.39 & 36.58 & 28.40 & 36.58 & 1.02 \\
\hline M0040A & 19.7963 & 150.4814 & 126.07 & 132.67 & 12 & 21.50 & 11.73 & 54.56 & 21.50 & 54.56 & 0.61 \\
\hline M0041A & 19.7963 & 150.4815 & 126.58 & 132.67 & 12 & 22.10 & 10.06 & 45.52 & 22.10 & 45.52 & 0.55 \\
\hline M0042A & 19.8440 & 150.4480 & 50.78 & 56.32 & 29 & 46.40 & 10.94 & 23.58 & 46.40 & 23.58 & 2.19 \\
\hline M0043A & 19.7989 & 150.4794 & 102.93 & 107.88 & 23 & 35.00 & 6.04 & 17.26 & 35.00 & 17.26 & 0.85 \\
\hline M0044A & 19.7985 & 150.4796 & 105.25 & 104.31 & 9 & 11.00 & 1.67 & 15.18 & 11.00 & 15.18 & 0.72 \\
\hline M0045A & 19.7984 & 150.4976 & 105.25 & 105.01 & 4 & 14.60 & 0.00 & 0.00 & 14.60 & 0.00 & 0.24 \\
\hline M0046A & 19.7985 & 150.4796 & 117.49 & 120.41 & 11 & 20.40 & 2.52 & 12.35 & 20.40 & 12.35 & 0.45 \\
\hline M0049A & 15.4724 & 145.8237 & 97.63 & 98.61 & 2 & 3.50 & 0.77 & 22.00 & 3.50 & 22.00 & 0.24 \\
\hline M0049B & 15.4724 & 145.8237 & 97.63 & 100.00 & 13 & 15.60 & 2.79 & 17.88 & 15.60 & 17.88 & 0.52 \\
\hline M0050A & 15.4723 & 145.8237 & 97.63 & 98.20 & 6 & 10.50 & 1.87 & 17.81 & 10.50 & 17.81 & 0.27 \\
\hline M0051A & 15.4721 & 145.8230 & 78.13 & 80.90 & 2 & 2.50 & 0.15 & 6.00 & 2.50 & 6.00 & 0.35 \\
\hline M0052A & 17.1011 & 146.5763 & 97.63 & 103.70 & 1 & 1.40 & 1.30 & 92.86 & 1.40 & 92.86 & 0.25 \\
\hline M0052B & 17.1011 & 146.5763 & 97.63 & 103.70 & 4 & 6.90 & 0.46 & 6.67 & 6.90 & 6.67 & 0.30 \\
\hline M0052C & 17.1011 & 146.5763 & 97.63 & 106.80 & 2 & 1.90 & 0.10 & 5.26 & 8.80 & 5.26 & 0.22 \\
\hline M0053A & 17.1012 & 146.5763 & 97.87 & 104.60 & 33 & 37.30 & 12.18 & 32.65 & 37.30 & 32.65 & 1.59 \\
\hline M0054A & 17.1007 & 146.5767 & 107.23 & 110.33 & 6 & 9.30 & 2.23 & 23.98 & 18.72 & 11.91 & 1.06 \\
\hline M0054B & 17.1007 & 146.5767 & 107.23 & 110.33 & 12 & 27.84 & 8.25 & 29.63 & 33.20 & 24.85 & 2.26 \\
\hline M0055A & 17.1019 & 146.5747 & 87.33 & 93.06 & 10 & 28.50 & 10.00 & 35.09 & 31.29 & 31.96 & 0.89 \\
\hline M0056A & 17.1022 & 146.5741 & 81.22 & 85.56 & 16 & 40.20 & 12.73 & 31.67 & 41.29 & 30.83 & 1.05 \\
\hline M0057A & 17.1050 & 146.5640 & 42.27 & 47.67 & 16 & 40.60 & 19.00 & 46.80 & 41.78 & 45.48 & 1.30 \\
\hline M0058A & 17.0973 & 146.5893 & 167.14 & 172.41 & 15 & 41.40 & 33.94 & 81.98 & 41.40 & 91.98 & 1.06 \\
\hline
\end{tabular}

2) reconstruct the nature and magnitude of seasonal to millennial scale climate variability (e.g., SST, SSS)

3) determine the biologic and geologic response of the GBR to abrupt sea-level and climate changes.

In this report we present a first summary of the operations, preliminary sedimentologic, chronologic, petrophysical, paleomagnetic, and geochemistry results and their implications and discuss the future plans for the post-cruise science.

\section{Operations}

The drilling platform chosen for Exp. 325 was the Greatship Maya, an IMO Class II dynamically positioned vessel with geotechnical coring capability. Operations were conducted between 12 February and 6 April 2010 (Table 1). Cyclone Ului, combined with several serious technical difficulties (Webster et al., 2011), meant that total percent recovery of the GBR cores was lower than IODP 310 Tahiti Sea Level (57.5\% for Tahiti, whereas $27.2 \%$ for GBR; Camoin et al., 2007; Webster et al., 2011). 


\section{Science Reports}

The vessel was equipped with a large moon pool and Bluestone TT150 derrick, capable of handling 9-m string lengths, with a Foremost Hydraulic top drive and relative motion-compensating heave (2.5-m stroke cylinders). Wireline operation of the core barrel was conducted through the top drive. Deployment of the wireline logging tools was conducted through the mud valve at the top of the top drive, from the rooster box, providing a heave compensated platform from which to zero in the tools.

Two types of QDTech coring tools were carried: an extended nose corer (EXN; equivalent to the extended core barrel $[\mathrm{XCB}]$ ), and a standard rotary corer (ALN; equivalent to the rotary core barrel [RCB]), along with four bottom-hole

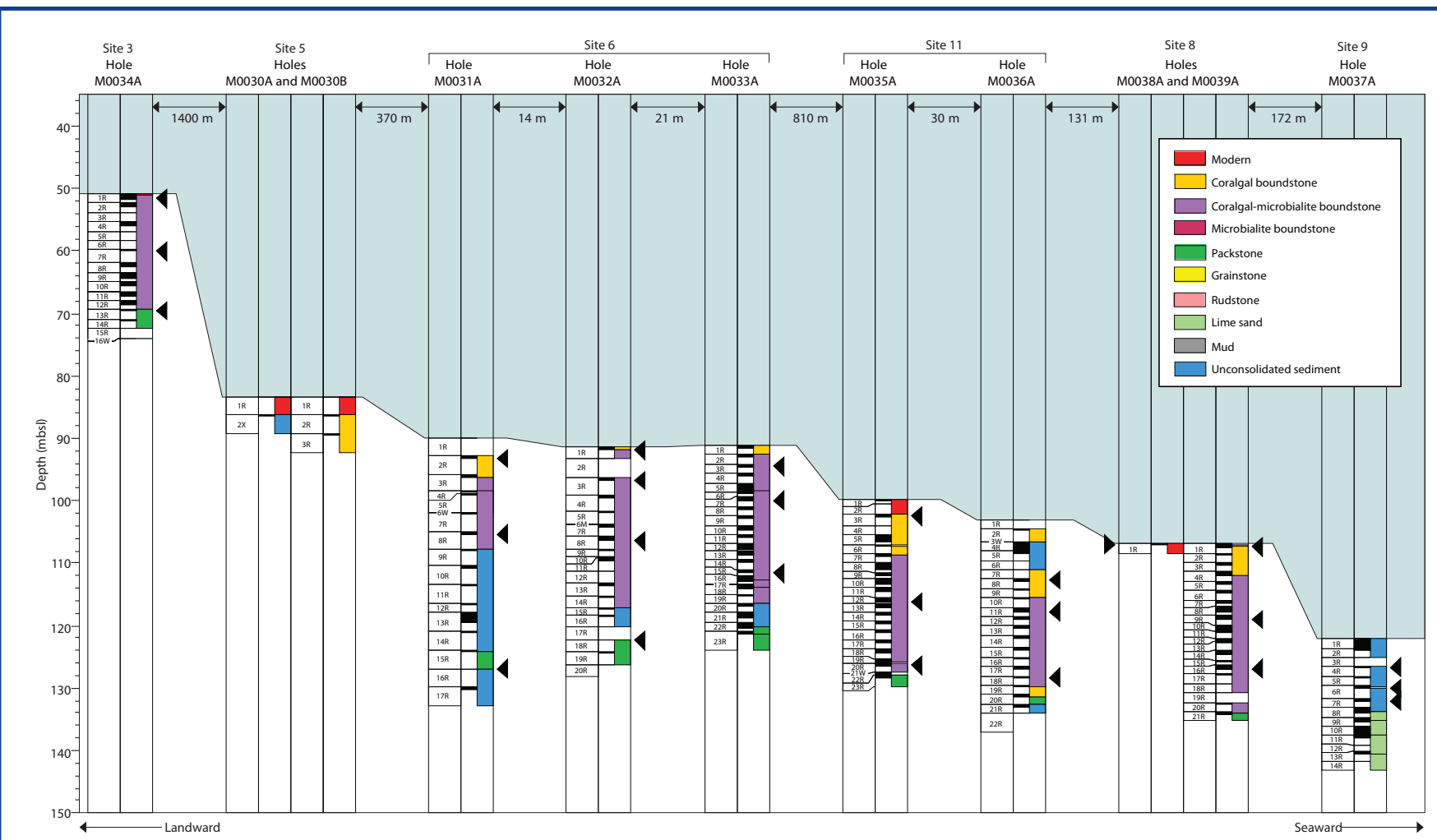

Figure 4. Lithostratigraphic summary of holes on the Transect HYD-02 (Sites from landward to seaward; M0034A, M0030A, M0030B, M0031A, M0032A, M0033A, M0035A, M0036A, M0038A, M0039A, and M0037A).

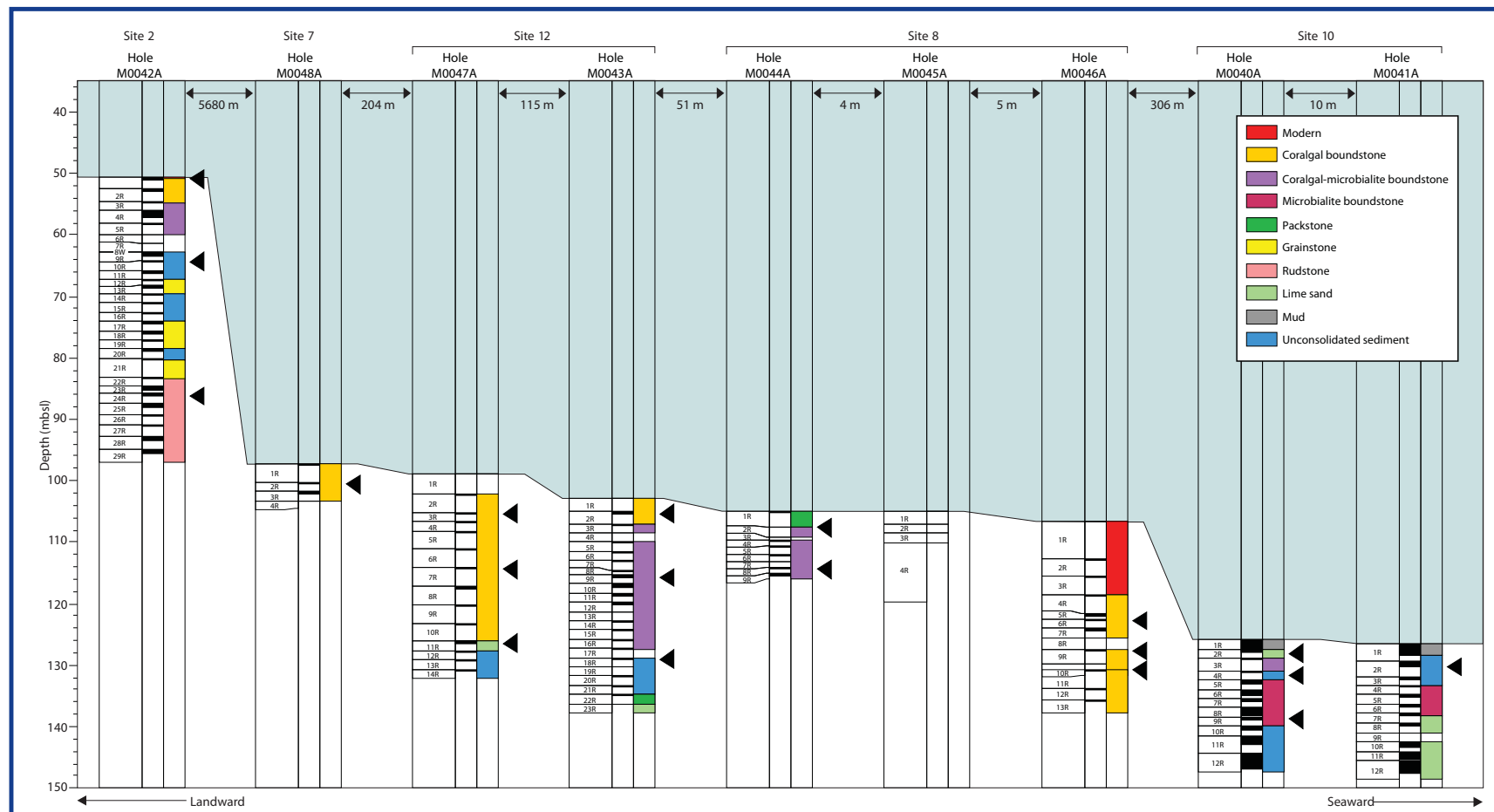

Figure 5. Lithostratigraphic summary of holes on the Transect HYD-01 (Sites from landward to seaward; M0042A, M0048A, M0047A, M0043A M0044A, M0045A, M0046A, M0040A, and M0041A). 
assemblies (BHAs), two each to fit the American Petroleum Institute (API) 4-inch-bore inner diameter string, and the Longyear HQ mining drill string.

At each site a pre-coring downpipe camera survey was conducted as part of the Environmental Management Plan agreed with the Great Barrier Reef Marine Park Authority (GBRMPA). Very strong bottom currents required the use of a seabed template to stabilize the drill string.

Offshore, the cores were carefully curated by ESO staff before ephemeral physical (multi-sensor core logger, MSCL), geochemical, and microbiological properties were measured and preliminary samples taken. Initial lithological and coral descriptions were conducted by visual inspection through the liner and using core catcher materials. No further sampling, core splitting, or analysis work was undertaken offshore.

All cores and data were transferred to the IODP Core Repository at Bremen, Germany (BCR) at the end of the offshore phase. Prior to the start of the Onshore Science Party (OSP), additional thermal conductivity measurements and computed tomography (CT) scans were undertaken on selected whole core sections. All the cores were assessed for the presence of massive corals, so as to instruct the core splitting procedure used. The complete Science Party plus ESO and BCR personnel and student helpers met at the BCR on 2-16 July to split, analyze, and sample the cores according to standard IODP procedures.

\section{Sedimentology}

Sedimentological investigation of the cores was conducted during both the offshore and onshore phases of operations. Nine lithogical types were recognized, and their main characteristics and distributions as distinct lithostratigraphic units are shown in Figs. 4-7 and summarized below.

Modern or sub-recent deposits consisting of lime sand to pebbles, locally in a muddy matrix, cover the boundstone lithologies at the top of a number of holes. Pebbles are made up of coralgal boundstone, coralline algae (some of them with reddish-pinkish color, indi-

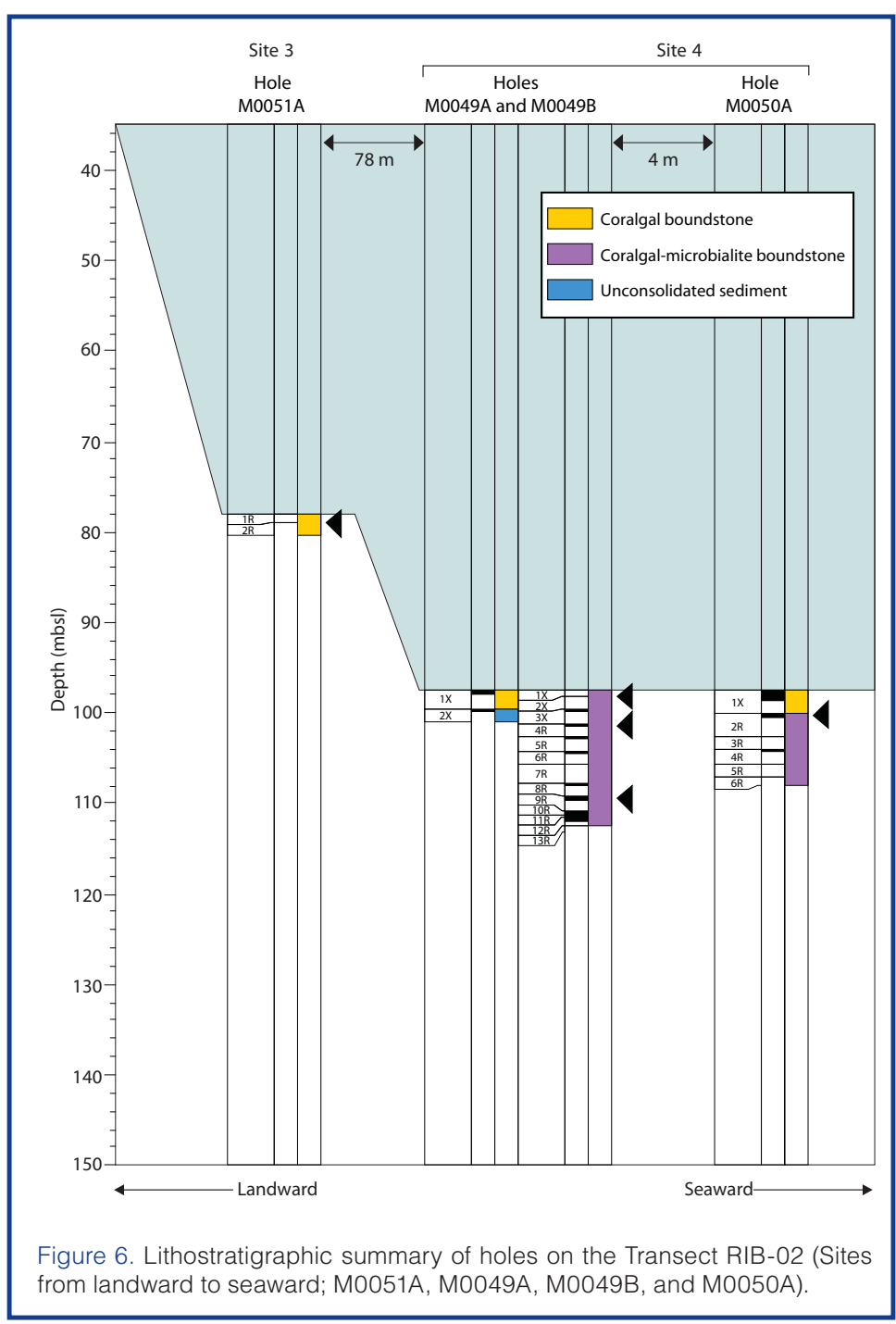

from landward to seaward; M0051A, M0049A, M0049B, and M0050A) 
cating they were alive when recovered), serpulid worm tubes, mollusk shells and bryozoans. Some pebbles have brown staining. Halimeda have been identified, as well as larger benthic foraminifera (abundant and well-preserved or stained specimens of Alveolinella, Amphistegina, Cycloclypeus, Elphidiidae, Heterostegina, Operculina, and Sphaerogypsina).

Coralgal-microbialite and coralgal boundstones are the dominant lithologies in the recovered deposits (Fig. 3). The coralgal-microbialite boundstones, $10-30 \mathrm{~m}$ thick, are composed of corals partially coated by coralline algae and vermetids encrusted by microbialites, which volumetrically are the major component (Figs. 4-7). Halimeda, mollusks, benthic foraminifera, red algae, bryozoans, and echinoderms occur as pockets of internal sediment in the coralgal-microbialite frameworks. Coral assemblages are dominated by massive Isopora, branching Acropora, and Seriatopora, but massive Porites and Faviidae are locally abundant. Hydrolithon onkodes is the most abundant coralline alga, together with Lithophyllum prototypum and Neogoniolithon fosliei. Amphistegina, Operculina, Heterostegina, and Alveolinella are the most common larger benthic foraminifera. The relative proportions of coral, coralline algae, and microbialite vary within this lithology. The coralgal lithologies, ranging from $1 \mathrm{~m}$ to $24 \mathrm{~m}$ in thickness, only differ from the coralgal-microbialite boundstone in containing little or no microbialite.

Stratigraphically, the coralgal boundstones consistently overlie coralgal-microbialite units. However, in two holes (M0034A, M0055A) a thin unit of coralgal boundstone underlies a thicker coralgal-microbialite interval, and in five other holes (Holes M0046A, M0047A, M0048A, M0052A, $\mathrm{M} 0057 \mathrm{~A})$ a coralgal framestone is the only recovered lithology bound by organisms (Figs. 5, 7).

Unconsolidated sediment $<1-19 \mathrm{~m}$ thick underlies the coralgal-microbialite and coralgal boundstone units and is composed of bioclastic lime sand to pebbles containing mollusks, larger benthic foraminifera, Halimeda, fragments of corals and red algae, bryozoans, and echinoderms. In Hole M0036A, an unconsolidated unit $6 \mathrm{~m}$ in thickness is bracketed by coralgal boundstone, whereas in Hole M0037A-the most distal and deepest site $(122 \mathrm{~m})$ on the HYD-01A transect (Fig. 4) - only unconsolidated sediment was recovered. These unconsolidated sediments were likely to have been partly disturbed by coring operations.

Skeletal packstone to grainstone, up to $13 \mathrm{~m}$ thick, underlies the unconsolidated sediment or the coralgal/ coralgal-microbialite boundstones in most holes. These lithologies are variably cemented and composed of fragments of shells, coral, coralline algae, Halimeda, and abundant larger benthic foraminifera. The top of the cemented lithologies is commonly bored by worms and sponges. Features indicating subaerial exposure, such as calcrete deposits, brownish staining, and rhizoliths, appear at the top of grainstones in the shallowest holes on transect NOG-01B. In Hole M0036A, a dark-colored boundstone, about $1.5 \mathrm{~m}$ thick, overlies the packstone. This blackened boundstone is made up of encrusting coral and thin coralline algae in its upper part, and a boundstone of coral, thin foliose coralline algae, and worm tubes in the lowest $10 \mathrm{~cm}$. The dominant coral is massive Goniopora, with fragments of massive Faviidae and finebranching Seriatopora.

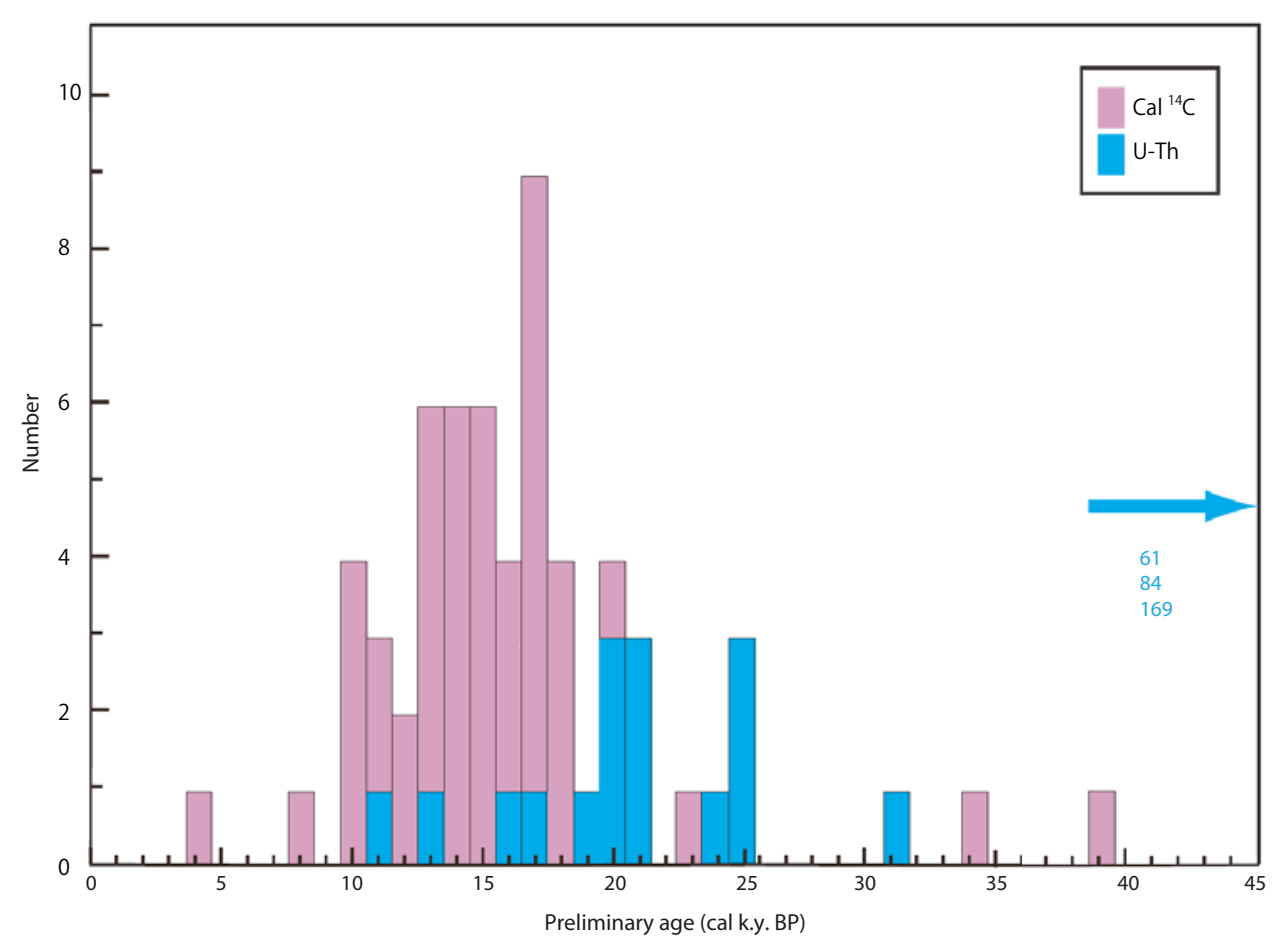

Figure 8. Age histograms of preliminary dating samples (1-ky rounded). All ages are in years before AD 1950. Numbers in blue listed below the arrow indicate $3 \mathrm{U} / \mathrm{Th}$ ages obtained for older samples.
Below the uppermost packstone-grainstone, a variety of lithologies were encountered. In the shallowest three holes on NOG-01B (Fig. 7) transect coralgal and coralgal-microbialite boundstones alternate with packstone-grainstone units, reaching up to $25 \mathrm{~m}$ in total thickness. All lithologies show dissolution surfaces, brownish stainings, and dissolution of aragonitic components. These features suggest several phases of emersion and weathering. In other holes, unconsolidated sediment underlies or alternates with cemented inter-vals of packstones and grainstones. In the deep holes of transects HYD-01C 
(M0037A) and NOG-01B (M0053A and M0054A-B) lime sand rich in larger foraminifera and mollusks underlies the consolidated lithologies. Although there is clear evidence of downhole contamination in their upper part, these deposits appear to be undisturbed and are probably in situ, with minimal disturbance from downhole contamination. No consistent pattern has yet been extracted in the succession of these units.

Finally, the deepest hole of Exp. 325 was M0058A at a depth $167 \mathrm{~m}$ in the fore-reef slope; it recovered 41 meters of mainly unconsolidated green mud with two intercalated units of fine to medium sand and a few grainstone intervals. The three mud units in M0058A are characterized by a lack of bedding and scattered small fragments of mollusk shells and benthic foraminifera tests. The sand/grainstone units are up to $7 \mathrm{~m}$ thick and consist of fine to medium sand with fragments of well-cemented grainstone, mollusks, bryozoa, coralline algae, echinoids, larger foraminifera, and serpulids.

\section{Chronology}

Preliminary dating provided an important overview of the age of the material recovered during the offshore phase of Exp. 325. Subsamples of core catcher material (coral and mollusk) were taken during the offshore phase for U-Th or radiocarbon dating. The dated samples were free of visible diagenetic features of detrital contamination. Additional diagenetic screening of these samples using $\mathrm{XRD}$ and SEM is ongoing. To constrain the basic chronology of each hole, we collected samples from representative core sections from the top, middle, and bottom of the hole. A total of sixty-eight samples were sent to the University of Tokyo (Japan) and the University of Oxford (United Kingdom) for dating. Radiocarbon samples, after being graphitized at University of Tokyo, were transferred to the Australian National University for analysis by AMS (Accelerator Mass Spectrometry). To ensure that the chronological control on the lower portions of holes was not limited by the range of the radiocarbon chronometer ( 50 cal k.y. BP [ 50 thousand calendar years BP]), the deeper samples from each hole were selected for U-Th analysis, and the shallower samples were analyzed for radiocarbon (see Webster et al., 2011 for detailed information).

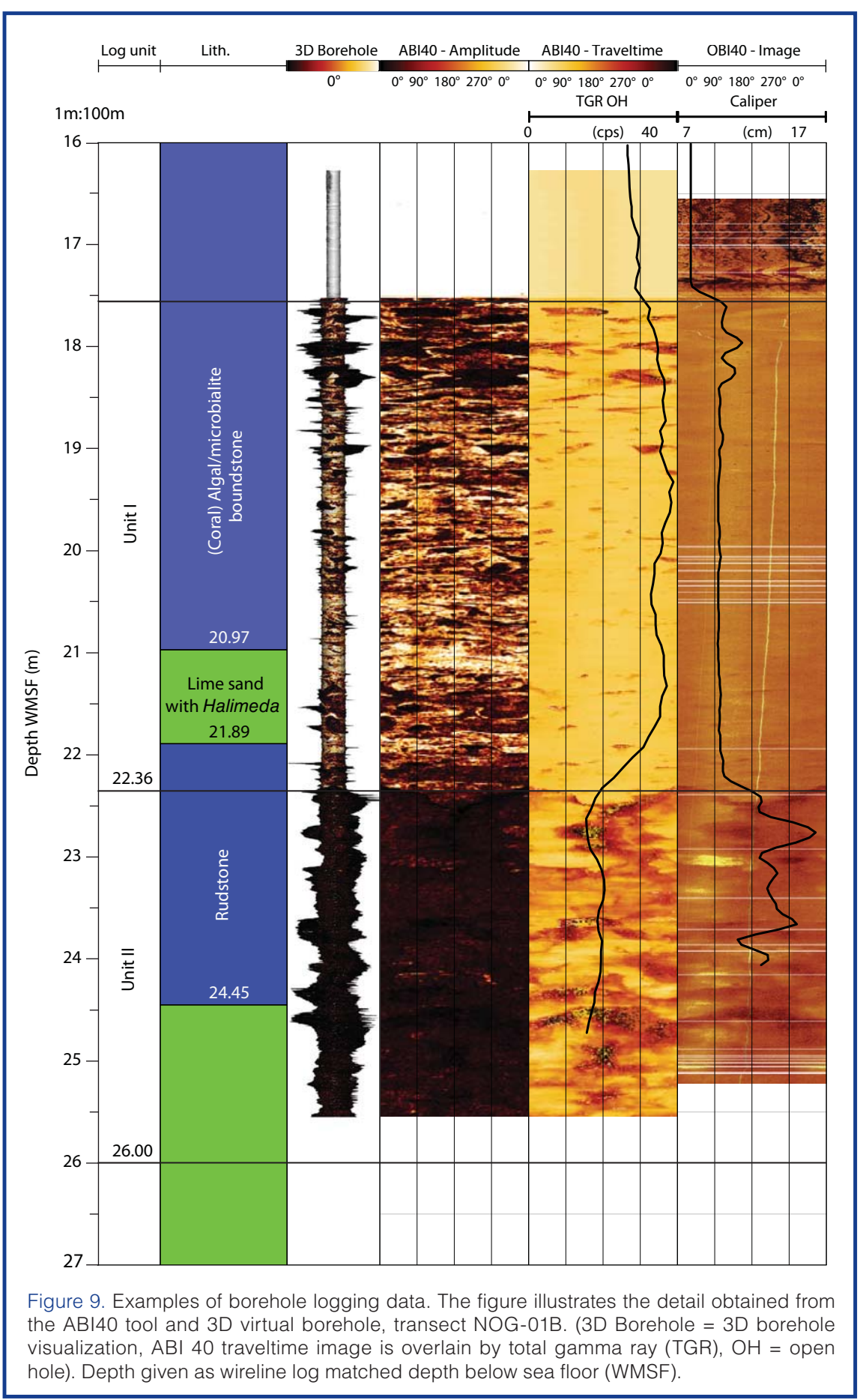

Except for Hole M0037A, all sample ages in all of the holes are in stratigraphic order. This provides confidence in the accuracy of the dates, and it ensures that the cores have sampled in situ reef framework, consistent with the sedimentologic observations. The majority of the deeper holes have U-Th dates near their bases that indicate the Last Glacial Maximum (LGM) was sampled, ranging between 20 cal k.y. BP and 25 cal k.y. BP (Fig. 8). Shallower samples from these cores (dated by radiocarbon) indicated dates as recent as 13-14 cal k.y. BP, which suggests that the early portion of the deglacial has also been captured by Exp. 325 drill cores. Holes drilled in shallower water have ages as young as 10 cal k.y. BP, indicating that early Holocene coral reef samples have been collected. This data opens up the 
possibility of comparison between these sites in the GBR with other localities that were drilled from onshore rigs. There appears to be a sharp decline in the number of samples postdating 10 cal k.y. BP (Fig. 8). This may reflect a reef drowning event at this time or may simply be an artifact of the relatively small dataset and/or a sampling bias.

U-Th ages prior to the LGM show promise for recovering high-quality material for dating of earlier periods in the Pleistocene. Holes M0032A, M0056A, and potentially M0033A have material from Marine Isotope Stages 4 and 3, whereas Hole M0042A may provide material from the transition between marine isotope Stages 7 and 6 . Hole M0057A has U-Th isotope ratios that suggest that the age of the samples is older than the LGM and, although not yielding a closed system U-Th age due to its intermediate depth, this hole may enable insights into glacial-interglacial transitions older than the last interglacial.

\section{Petrophysics}

A set of slimline borehole logging probes was chosen on the basis of the scientific objectives and geological setting of the expedition. The tool suite used during Exp. 325 comprised probes with the capability of yielding a variety of data including high resolution borehole images (optical [OBI40] and acoustic [ABI40] borehole televiewers; Fig. 9), borehole fluid characterization (IDRONAUT), borehole diameter (CAL3), and a variety of petrophysical measurements such as electrical conductivity (DIL45), acoustic velocity (SONIC), spectral natural gamma radiation (ASGR), and magnetic susceptibility (EM51). Downhole logging was performed in a total of four boreholes, with the majority of measurements being taken in open hole. The only exception to this was a preliminary spectral gamma log conducted through-pipe in each hole.

Downhole logging units were identified on the basis of combined data signatures. These logging divisions were found to be largely coincident with the lithostratigraphic units defined by core description (Fig. 9). A combination of
A

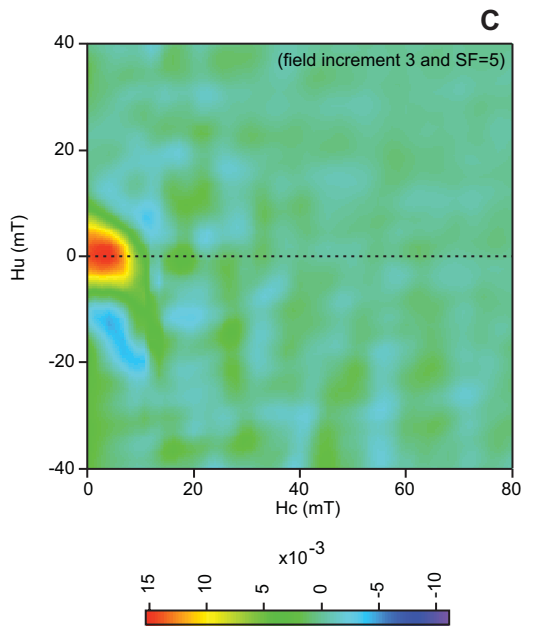

B

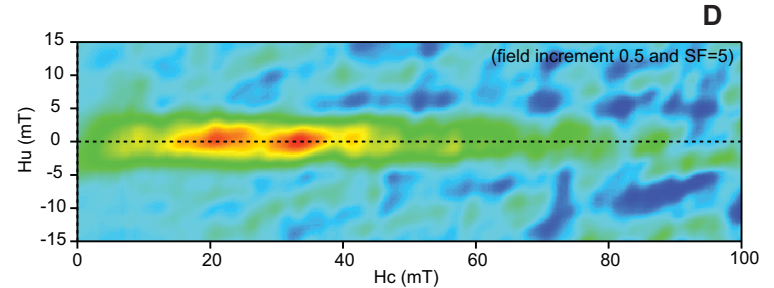

D

Figure 10. Hysteresis loops, back-field curve ([A], [B]) and first-order reversal curve (FORC) ([C], [D]) of samples from Hole M0058A and M0041A performed with software package FORCinel (Harrison and Feinberg, 2008). The sample from Hole M0058A (field increment $3 \mathrm{mT}$ and SF=5) shows rock magnetic properties mainly of a low coercivity material terrigenous magnetite. The sample from M0041A shows the presence of non-interactive SD magnetite that may represent the presence of magnetosomes.

whole core, split core, and discrete sampling petrophysical measurements were taken on the expedition cores. These measurements include density and porosity, resistivity, P-wave velocity, magnetic susceptibility, thermal conductivity, and color reflectance spectrophotometry. All cores recovered during the expedition were measured where appropriate and possible to do so. Multivariate analysis relating the physical properties data with different coralgal assemblage compositions (Lado-Insua et al., 2010) indicate that it is possible to infer important composition information from the petrophysical dataset. This has the potential for use as a proxy for the identification of sample types from the nondestructive, offshore physical properties measurements in future research. Future work planned by the Exp. 325 Science Party will move towards improving and furthering the integration of the different petrophysical and lithological datasets.

\section{Paleomagnetics}

A total of thirty cores were provided for paleomagnetic measurements. The AF demagnetization of the U-channels and of discrete samples from the fore-reef slope Hole M0058A suggests the presence of magnetic impurities and potential deformation during drilling operations. However, the magnetic susceptibility and artificial remnant magneti- 


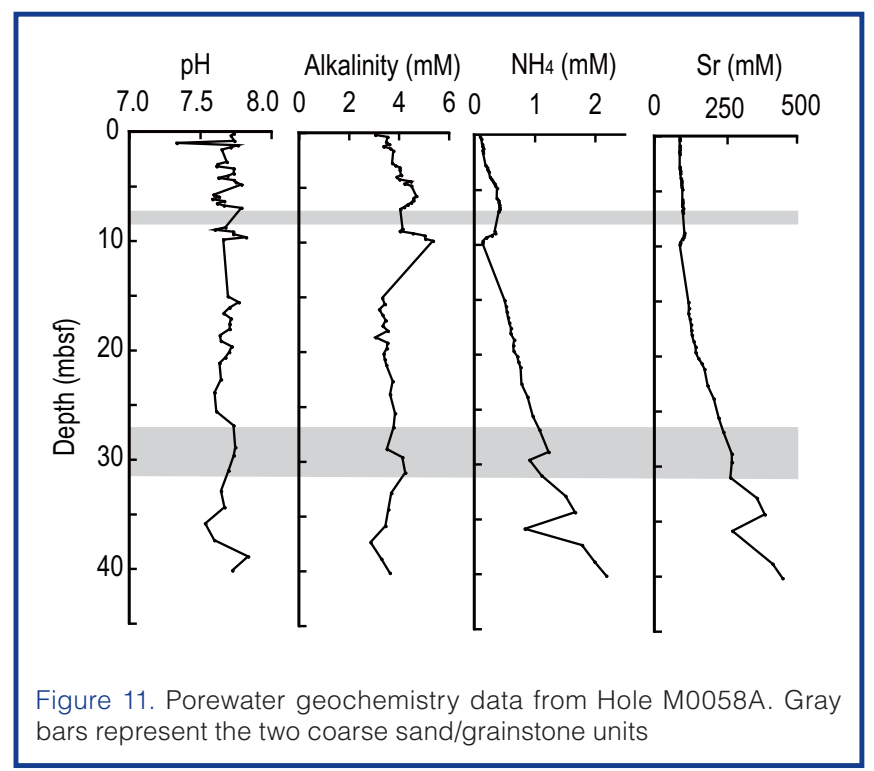

zations such as anhysteretic (ARM), isothermal (IRM), and indirect parameters (ARM/IRM, S-ratio, and HIRM) show clear separations, with two horizons of high concentrations of a low coercivity magnetic mineral (Webster et al., 2011). Rock magnetic properties confirm that the magnetic carrier is magnetite (Fig. 10a, 10c) with the two horizons characterized by a mixture of low and high-coercivity minerals. The magnetic horizons may correspond to two periods of higher terrigenous sediment input that likely correlate with the two sand/grainstone lithologic units observed in the core. While in the shelf edge fossil reef cores (e.g., M0041), a non-interactive single domain (SD) low coercivity mag-netic mineral (probably magnetite) was measured in discrete samples from fossil coral materials. We attribute that to the presence of magnetosomes of magnetotactic bacteria (Fig. 10b, 10d; Egli et al., 2010). Further studies of rock magnetic properties will provide more detailed information and help establish the nature of relationships between magnetic properties, coral formation, and climate change.

\section{Geochemistry}

A total of 115 interstitial water (IW) samples were acquired during Exp. 325, from transects of HYD-01C (16), HYD-02A (20), RIB-02A (2), and NOG-01B (77). (Numbers in parentheses indicate the number of samples obtained from each transect.) The majority of the IW samples was collected from the holes drilled into the carbonate reef complex of the GBR. The $\mathrm{pH}$, alkalinity, and ammonium concentrations of IW collected from the holes drilled into the carbonate reef complex did not indicate any apparent depth-related or transect-specific variation, probably due to the scarcity of IW samples at each transect.

However, Hole M0058A (NOG-01B transect) consisted of fine to coarse sediments, unlike other holes, and therefore continuous IW sampling was possible. While there was no systematic vertical variation in the $\mathrm{pH}$, alkalinity, and

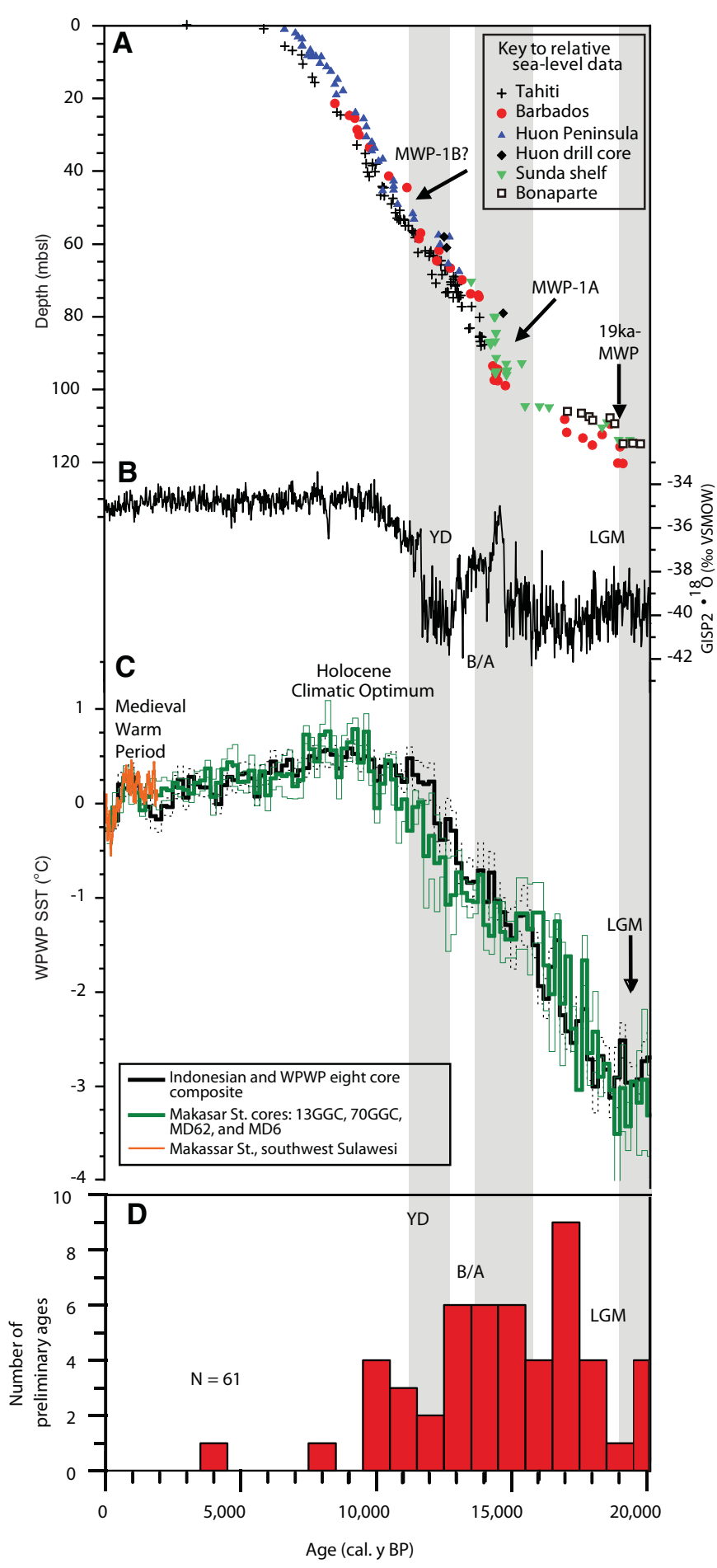

Figure 12. Comparisons of preliminary dating results and previously published sea-level and climatological data. [A] Previously published data on relative sea level from $20 \mathrm{cal} \mathrm{k.} \mathrm{y.} \mathrm{BP} \mathrm{through} \mathrm{present.} \mathrm{MWP=}$ meltwater pulse. [B] GISP2 $\delta^{18} \mathrm{O}$ proxy for temperature over Greenland. [C] Sea-surface temperature variation in the Western Pacific Warm Pool (WPWP) (Linsley et al., 2010). [D] Histogram showing preliminary dating results on core catcher samples. Age distribution clearly indicates that the recovered fossil coral reef cores cover key intervals of interest for sea-level changes and environmental reconstruction, including the last glacial maximum (LGM), Bölling-Alleröd (B/A), and Younger Dryas (YD). Sources of data: Tahiti = Bard et al., 1996, 2010; Huon Peninsula = Chappell and Polach, 1991; Edwards et al., 1993; Huon drill core = Cutler et al., 2003; Sunda shelf = Hanebuth et al., 2000; Barbados = Fairbanks, 1989; Bard et al., 1990; Bonaparte = Yokoyama et al., 2000b; 2001a; DeDeckker and Yokoyama, 2009. GISP2 = Stuiver and Grootes, 2000. 
chloride, the ammonia and strontium concentrations increased with depth (Fig. 11). The notable characteristic of IW from Hole M0058A is that two large anomalies occur coincident with the two sand/grainstone lithologic units, in the profiles for total iron and manganese concentrations. The percentage quartz profile of the sediments displayed the opposite trend to that of percentage carbonate. These litho-logic units also contain low total organic carbon content, with an average value of $0.25 \%$, compared to the rest of the core. Consistent with the paleomagnetic data, these findings suggest that the two sand/grainstone units may correspond to the increased input of terrestrial material during their deposition. Further investigations are needed to fully understand the cause of lithologic changes found at Hole M0058A.

\section{Microbiology}

The subsurface microbial ecology will be characterized using multiple molecular based techniques. Fine grain sediment cores collected from transect NOG-01B, Hole M0058A represent the bulk of microbiological sampling. Sediment was collected for cell enumeration and phylogenetic analysis during shipboard and onshore operations. Shipboard samples were taken at multiple depths downcore, immediately frozen at $-80^{\circ} \mathrm{C}$ for the duration of the cruise and then shipped on dry ice to labs in the United States (Texas A\&M University) and China (China University of Geosciences). Onshore, sediment was collected from locations adjacent to the samples collected during the offshore phase. These samples are designed to test shifts in microbial community activity and structure during $4^{\circ} \mathrm{C}$ transit to, and storage in, Bremen, Germany against those samples collected immediately after coring that were frozen offshore. Samples remained at $4^{\circ} \mathrm{C}$ for approximately three months prior to shore-based sampling. Microbial communities in both shipboard and onshore sediment samples will be described for total structure and function using DNA- and RNA-based molecular targets, respectively. For cell enumeration, onshore sediment samples were preserved in $4 \%$ formaldehyde and stored at $4^{\circ} \mathrm{C}$. By combining all microbial data, the total, potential, and active communities can be determined. The analysis will provide a unique advance in understanding subsurface microbial ecology, as well as a description of potential sediment composition and chemistry altering biological processes that may occur during standard IODP $4^{\circ} \mathrm{C}$ storage.

\section{Concluding Remarks and Future Plans}

During the course of IODP Expedition 325 offshore phase, thirty-four holes were drilled, obtaining 225 meters of core materials from water depths ranging from $42 \mathrm{mbsl}$ to 167 mbsl (Fig. 12). The preliminary chronology of core catcher materials dated by both radiocarbon and U-series methods prior to the OSP provided a firm chronological framework for conducting further scientific analyses.
Fulfillment of the Exp. 325 scientific objectives can be seen as follows:

1. Reconstruct the course of postglacial sea-level change in GBR from $20 \mathrm{ka}$ to $10 \mathrm{ka}$. Coral-algal-microbialite lithologies of in situ and robust Isopora and Acropora assemblages are indicative of very shallow reef environments. They will contribute to the reconstruction of a robust sea-level curve from the LGM to $10 \mathrm{ka}$.

2. Establish sea-surface variations in the GBR from $20 \mathrm{ka}$ to $10 \mathrm{ka}$. preliminary chronologic results clearly show that important coral reef deposits were recovered consisting of key paleoenvironmental intervals including LGM, Bölling-Alleröd, Younger Dryas, and Heinrich events. Massive coral colonies suitable for paleoclimate studies will help define SST variations and aid paleoceanographic reconstruction for the region.

3. Investigate the response of the GBR to environmental changes caused by sea-level and climate changes. Cores were recovered from various locations and water depths along the GBR. Their large geographical spread and shelf edge position will allow the results to be interpreted in both a broad temporal and spatial context, allowing a better understanding of the development of the GBR in response to environmental changes.

In addition to the main scientific outcomes summarized above, we expect three additional scientific outcomes will be achieved.

1. It is believed that sea-level and paleoclimate information can be extended back to the LGM and pre-LGM periods based on the preliminary age determinations. This will enable a reconstruction of the evolution of the GBR during these earlier periods.

2. High-resolution paleoenvironmental information obtained from a nearly continuous 41-m sediment core in the fore-reef slope of Noggin Pass (M0058A) will complement the sea-level and paleoenvironmental records obtained from reef cores recovered from shallower shelf sites.

3. The microbial community structure and function will also be assessed within the Hole M0058 sediments using direct count microscopy and RNA/DNA gene targets. Correlations will be made between offshore and onshore geochemical characterizations in order to better describe the subsurface biosphere ecology.

Future work will now focus on more detailed sedimentological, petrophysical, geochemical, and geophysical investigations in the various laboratories of the IODP Exp. 325 Science Party members. The results obtained from these 
studies will improve our understanding of sea-level and climate change as well as coral reef response since the LGM.

\section{Acknowledgements}

We are grateful to Great Barrier Reef Marine Park Authority (GBRMPA), to the captains and crew of the RV Great Ship Maya, to Dan Evans, David Smith, Colin Graham, David McInroy, Dave Wallis, Graham Tulloch, Lee Baines, Mary Mowat, Martin Kölling, Richard le Provost, Jan Hoffman, Simon Barry and the rest of the ESO support staff of the mission-specific operations for ECORD, and to Ursula Röhl, Holger Kuhlmann, Alex Wülbers and the BCR staff in Bremen. Without these individuals and the many others left unnamed, the Great Barrier Reef Coral Reef operations would not have been possible. The work presented here was partly supported by JSPS (NEXT program GR031), GCOE, and the Australian Research Council (DP109400).

\section{IODP Expedition 325 Scientists}

Y. Yokoyama (Co-ChiefScientist), J. M. Webster (Co-Chief Scientist), C. Cotterill (Staff Scientist), L. Anderson, S. Green, R. Bourillot, J.C. Braga, A. Droxler, T.M. Esat, T. Felis, K. Fujita, M. Gagan, E. Gischler, E. Herrero-Bervera, J. Hongchen, M. Humblet, M. Inoue, T. Lado Insua, Y. Iryu, L. Jovane, H. Kan, B. Linsley, D. Loggia, H. Mills, D. Potts, C. Seard, A. Suzuki, A. Thomas, W. Thompson, M. Tiwari, and A. Tudhope.

\section{References}

Abbey, E., Webster, J.M., and Beaman, R., submitted. Morphology and origin of submerged features along the shelf edge of the Great Barrier Reef, Australia. Mar. Geol.

Abbey, E.A., and Webster, J.M., 2011. Submerged reefs. In Hopley, D. (Ed.), Encyclopaedia of Modern Coral Reefs: New York (Springer-Verlag), 1236.

Abram, N., Gagan, M.K., Cole, J.E., Hantoro, W., and Mudelsee, M., 2008. Coral evidence for a recent intensification of the Indian Ocean Dipole. Nature Geosci., 1:849-853, doi:10.1038/ngeo357.

Alexander, I., Wilson, P.A., Cooper, M.J., and International Consortium Great Barrier Reef Drilling, 2001. New constraints on the origin of the Australian Great Barrier Reef: Results from an international project of deep coring. Geology, 29(6):483-486, doi:10.1130/0091-7613(2001)029 $<0483$ :NCOTOO >2.0.CO;2.

Alley, R.B., 1998. Palaeoclimatology-Icing the north Atlantic. Nature, 392(6674):335, doi:10.1038/32781.

Asami, R., Felis, T., Deschamps, P., Hanawa, K., Iryu, Y., Bard, E., Durand, N., and Murayama, M., 2009. Evidence for tropical South Pacific climate change during the Younger Dryas and the Bølling-Allerød from geochemical records of fossil Tahiti corals. Earth Planet. Sci. Lett., 288:96-107, doi:10.1016/j.epsl.2009.09.011.
Bard, E., Hamelin, B., and Delanghe-Sabatier, D., 2010. Deglacial Meltwater Pulse 1B and younger Dryas sea levels revisited with boreholes at Tathiti. Nature, 327:1235-1237.

Bard, E., Hamelin, B., and Fairbanks, R.G., 1990. U-Th ages obtained by mass spectrometry in corals from Barbados: Sea level during the past 130,000 years. Nature, 346:456-458, doi:10.1038/346456a0.

Bard, E., Hamelin, B., Arnold, M., Montaggioni, L.F., Cabioch, G., Faure, G., and Rougerie, F., 1996. Deglacial sea-level record from Tahiti corals and the timing of global meltwater discharge. Nature, 382:241-244, doi:10.1038/382241a0.

Bridge, T.C.L., Done, T.J., Beaman, R.J., Friedman, A., Williams, S.B., Pizarro, O., and Webster, J.M., 2011. Topography, substratum and benthic macrofaunal relationships on a tropical mesophotic shelf margin, central Great Barrier Reef, Australia. Coral Reefs, 30:143-153, doi:10.1007/s00338010-0677-3.

Broecker, W.S., 1994. Massive iceberg discharges as triggers for global climate change. Nature, 372:421-424, doi:10.1038/ $372421 \mathrm{a} 0$.

Camoin, G., Seard, C., Deschamps, P., Webster, J., Abbey, E., Braga, J.-C., Iryu, Y., Durand, N., Bard, E., Hamelin, B., Yokoyama, Y., and Thomas, A., 2010. Reef response to sea-level and environmental changes during the last deglaciation. IODP Expedition 310 "Tahiti Sea Level". Geophys. Res. Abstr., EGU2010-14988.

Camoin, G.F., Iryu, Y., McInroy, D.B., and the IODP Expedition 310 Scientists, 2007. IODP Expedition 310 reconstructs sea level, climatic, and environmental changes in the South Pacific during the last degraciation. Sci. Drill., 5:4-12, doi:10.2204 /iodp.sd.5.01.2007.

Chappell, J., and Polach, H., 1991. Post-glacial sea-level rise from a coral record at Huon Peninsula, Papua New Guinea. Nature, 349:147-149, doi:10.1038/349147a0.

Clark, P.U., Archer, D., Pollard, D., Blum, J.D., Rial, J.A., Brovkin, V., Mix, A.C., Pisias, N.G., and Roy, M., 2006. The middle Pleistocene transition: Characteristics, mechanisms, and implications for long-term changes in atmospheric pCO2. Quat. Sci. Rev., 25:3150-3184, doi:10.1016/j.quascirev. 2006.07.008.

Clark, P.U., Dyke, A.S., Shakun, J.D., Carlson, A.E., Clark, J., Wohlfarth, B., Mitrovica, J.X., Hostetler, S.W., and McCabe, A.M., 2009. The last glacial maximum. Science, 325:710714, doi:10.1126/science.1172873.

CLIMAP, 1981. Seasonal reconstruction of the Earth's surface at the last glacial maximum. Geological Society of America, Map and Chart Series, C36.

Cole, J.E., Dunbar, R.B., McClanahan, T.R., and Muthiga, N., 2000. Tropical Pacific forcing of decadal SST variability in the western Indian Ocean over the past two centuries. Science, 287:617-619, doi:10.1126/science.287.5453.617.

Cutler, K.B., Edwards, R.L., Taylor, F.W., Cheng, H., Adkins, J., Gallup, C.D., Cutler, P.M, Burr, G.S., and Bloom, A.L., 2003. Rapid sea-level fall and deep ocean temperature change since the last interglacial period. Earth Planet. Sci. Lett., 206(3-4):253-271, doi:10.1016/S0012-821X(02)01107-X.

Davies, P.J., Symonds, P.A., Feary, D.A., and Pigram, C.J., 1989. The 
evolution of the carbonate platforms of northeast Australia, controls on carbonate platform and basin development. Society of Economic Paleontologists and Mineralogists Special Publication, 44:233-258.

DeDeckker, P., and Yokoyama, Y., 2009. Micropalaeontological evidence for Late Quaternary sea-level changes in Bonaparte Gulf, Australia. Global Planet. Change, 66:85-92, doi:10.1016/j.gloplacha.2008.03.012.

DeLong, K., Quinn, T.M., Shen, C.C., and Lin, K., 2010. A snapshot of climate variability at Tahiti $9.5 \mathrm{ka}$ using a fossil coral from IODP Expedition 310. Geochem. Geophys. Geosyst., 11:Q06005, doi:10.1029/2009GC002758.

Denton, G.H., and Hughes, T.J., 1981. The Last Great Ice Sheets: New York (John Wiley and Sons).

Deschamps, P., Durand, N., Bard, E., Hamelin, B., Camoin, G., Thomas, A.L., Henderson, G.M., and Yokoyama, Y., 2009. Synchroneity of Meltwater Pulse 1A and the Bolling onset: New evidence from the IODP “Tahiti Sea-Level” Expedition. Geophys. Res. Abstr., 11(EGU2009-10233).

Edwards, R.L., Beck, J.W., Burr, G.S., Donahue, D.J., Chappell, J.M.A., Bloom, A.L., Druffel, E.R.M., and Taylor, F.W., 1993. A large drop in atmospheric $14 \mathrm{C} / 12 \mathrm{C}$ and reduced melting in the Younger Dryas, documented with 230Th ages of corals. Science, 260:962-968, doi:10.1126/science.260. 5110.962 .

Edwards, R.L., Chen, J.H., and Wasserburg, G.J., 1987. ${ }^{238} \mathrm{U}^{234} \mathrm{U}-$ ${ }^{230} \mathrm{Th}^{232} \mathrm{Th}$ systematics and the precise measurement of time over the past 500,000 years. Earth Planet. Sci. Lett., 81:175-192, doi:10.1016/0012-821X(87)90154-3.

Egli, R., Chen, A.P., Winklhofer, M., Kodama, K.P., and Horng, C.-S., 2010. Detection of noninteracting single domain particles using first-order reversal curve diagrams. Geochem. Geophys. Geosyst., 11, Q01Z11, doi:10.1029/2009GC002916.

Esat, T.M., and Yokoyama, Y., 2008. Issues in radiocarbon and U-series dating of corals from the last glacial period. Quat. Geochronol., 3:244-252, doi:10.1016/j.quageo.2007.11.004.

Fairbanks, R.G., 1989. A 17,000-year glacio-eustatic sea level record: Influence of glacial melting dates on Younger Dryas event and deep ocean circulation. Nature, 342:637-642, doi:10.1038/342637a0.

Fairbanks, R.G., Mortlock, R.A., Chiu, T.-C., Cao, L., Kaplan, A., Guilderson, T.P., Fairbanks, T.W., Bloom, A.L., Grootes, P.M., and Nadeau, M.-J., 2005. Radiocarbon calibration curve spanning 0 to 50,000 years BP based on paired ${ }^{230} \mathrm{Th} /$ ${ }^{234} \mathrm{U} /{ }^{238} \mathrm{U}$ and ${ }^{14} \mathrm{C}$ dates on pristine corals. Quat. Sci. Rev., 24:1781-1796, doi:10.1016/j.quascirev.2005.04.007.

Felis, T., Suzuki, A., Kuhnert, H., Dima, M., Lohmann, G., and Kawahata, H., 2009. Subtropical coral reveals abrupt earlytwentieth-century freshening in the western North Pacific Ocean. Geology, 37:527-530, doi:10.1130/G25581A.1.

Fujita, K., Omori, A., Yokoyama, Y., Sakai, S., and Iryu, Y., 2010. Sealevel rise during Termination II inferred from large benthic foraminifers: IODP Expedition 310, Tahiti Sea Level. Mar. Geol., 271:149-155, doi:10.1016/j.margeo.2010.01.019.

Gagan, M.K., Ayliffe, L.K., Hopley, D., Cali, J.A., Mortimer, G.E., Chappell, J., McCulloch, M.T., and Head, M.J., 1998. Temperature and surface-ocean water balance of the mid-
Holocene tropiacl western Paficic. Science, 279:1014-1018, doi:10.1126/science.279.5353.1014.

Gallup, C.D., Cheng, H., Taylor, F.W., and Edwards, R.L., 2002. Direct determination of the timing of sea level change during Termination II. Science, 295:310-313, doi:10.1126/ science.1065494.

Hanebuth, T., Stattegger, K., and Grootes, P.M., 2000. Rapid flooding of the Sunda Shelf: A late-glacial sea-level record. Science, 288:1033-1035, doi:10.1126/science.288.5468.1033.

Harrison, R.J., and Feinberg, J.M., 2008. FORCinel: An improved algorithm for calculating first-order reversal curve distributions using locally weighted regression smoothing, Geochem. Geophys. Geosyst., 9, Q05016, doi:10.1029/ $2008 \mathrm{GC} 001987$.

Hays, J.D., Imbrie, J., and Shackelton, N.J., 1976. Variations in the Earth's orbit: Pacemaker of the Ice Ages. Science, 194:11211132, doi:10.1126/science.194.4270.1121.

Inoue, M., Yokoyama, Y., Harada, M., Suzuki, A., Kawahata, H., Matsuzaki, H., and Iryu, Y., 2010. Trace element variations in fossil corals from Tahiti collected by IODP Expedition 310: Reconstruction of marine environments during the last deglaciation (15 to 9 ka). Mar. Geol., 271:303-306, doi:10.1016/j.margeo.2010.02.016.

Ivins, E.R., and James, T.S., 2005. Antarctic glacial isostatic adjustment: A new assessment. Antarct. Sci., 17:537-549, doi:10.1017/S0954102005002968.

Lado-Insua, T., Moran, K., Anderson, L., Webster, J.M., Morgan, S., Fehr, A., Lofi, J., Lukies, V., Loggia, D., and IODP Expedition 325 Scientists, 2010. Are physical properties able to differentiate glacial and interglacial coral identity? [American Geophysical Union, Fall Meeting, San Francisco, 13-17 December 2010] Abstract PP11E-1476.

Lambeck, K., Yokoyama, Y., and Purcel, A., 2002. Into and out of the Last Glacial Maximum: Sea-level change during oxygen isotope stages 3 and 2. Quat. Sci. Rev., 21:343-360, doi:10.1016/ S0277-3791(01)00071-3.

Linsley, B.K., Rosenthal, Y., and Oppo, D.W., 2010. Holocene evolution of the Indonesian throughflow and the western Pacific warm pool. Nature Geosci., 3(8):578-583, doi:10.1038/ ngeo920.

Milne, G.A., Gehrels, W.R., Hughes, C.W., and Tamisiea, M.E., 2009. Identifying the causes of sea-level change. Nature Geosci., 2:471-478, doi:10.1038/ngeo544.

Mix, A.C., Bard, E., and Schneider, R., 2001. Environmental processes of the ice age: Land, oceans, glaciers (EPILOG). Quat. Sci. Rev., 20:627-657, doi:10.1016/S0277-3791 (00)00145-1.

Nakada, M., and Lambeck, K., 1987. Glacial rebound and relative sealevel variations: A new appraisal. Geophys. J. Roy. Astr. Soc., 90:171-224.

Reimer, P.J., Baillie, M.G.L., Bard, E., Bayliss, A., Beck, J.W., Bertrand, C.J.H., Blackwell, P.G., Buck, C.E., Burr, G.S., Cutler, K.B., Damon, P.E., Edwards, R.L., Fairbanks, R.G., Friedrich, M., Guilderson, T.P., Hogg, A.G., Hughen, K.A., Kromer, B., McCormac, G., Manning, S., Ramsey, C.B., Reimer, R.W., Remmele, S., Southon, J.R., Steiver, M., Talamo, S., Taylor, F.W., van der Plicht, J., and Weyhenmeyer, 
C.E., 2004. Intcal04 terrestrial radiocarbon age calibration, 0-26 cal kyr BP. Radiocarbon, 46:1029-1058.

Seard, C., Camoin, G., Yokoyama, Y., Matsuzaki, H., Durand, N., Bard, E., Sepulcre, S., and Deschamps, P., 2011. Microbialite development patterns in the last deglacial reefs from Tahiti (French Polynesia; IODP Expedition \#310): Implications on reef framework architecture. Mar. Geol., 279:63-86, doi:10.1016/j.margeo.2010.10.013.

Solomon, S., Qin, D., Manning, M., Chen, Z., Marquis, M., Averyt, K.B., Tignor, M., and Miller, H.L., 2007. Climate Change 2007 - The Physical Science Basis. Contribution of Working Group I to the Fourth Assessment Report of the Intergovernmental Panel on Climate Change: U.K. and New York (Cambridge University Press).

Stirling, C.H., and Andersen, M.B., 2009. Uranium-series dating of fossil coral reefs: Extending the sea-level record beyond the last glacial cycle. Earth Planet. Sci. Lett., 284:269-283, doi:10.1016/j.epsl.2009.04.045.

Stirling, C.H., Esat, T.M., McCulloch, M.T., and Lambeck, K., 1995. High-precision U-series dating of corals from Western Australia and implications for the timing and duration of the Last Interglacial. Earth Planet. Sci. Lett., 135:115-130.

Stuiver, M., and Grootes, P.M., 2000. GISP2 oxygen isotope ratios. Quat. Res., 53:277-283, doi:10.1006/qres.2000.2127.

Thomas, A.L., Henderson, G., Deschamps, P., Yokoyama, Y., Mason, A.J., Bard, E., Hamelin, B., Durand, N., and Camoin, G., 2009. Penultimate deglacial sea level timing from uranium/ thorium dating of Tahitian corals. Science, 324:1186-1189, doi:10.1126/science.1168754.

Tudhope, A.W., Chilcott, C.P., McCulloch, M.T., Cook, E.R., Chappell, J., Ellan, R.M., Lea, D.W., Lough, J.M., and Shimmield, G.B., 2001. Variability in the El Niño-Southern Oscillation through a glacial-interglacial cycle. Science, 291(5508):15111517, doi:10.1126/science.1057969.

Webster, J.M., and Davies, P.J., 2003. Coral variation in two deep drill cores: Significance for the Pleistocene development of the Great Barrier Reef. Sediment. Geol., 159:61-80, doi:10.1016/ S0037-0738(03)00095-2.

Webster, J.M., Davies, P.J., Beaman, R.J., Williams, S., and Byrne, M., 2008. Evolution of drowned shelf edge reefs in the GBR; implications for understanding abrupt climate change, coral reef response and modern deep water benthic habitats. CSIRO Marine National Facility, RV Southern Surveyor voyage summary SS07/2007. http://www.marine.csiro.au/ nationalfacility/voyagedocs/2007/summarySS07-2007.pdf.

Webster, J.M., Yokoyama, Y., Cotterill, C., and the Expedition 325 Scientists, 2011. IODP Expedition 325. Proc. IODP, 325: Washington, DC (Integrated Ocean Drilling Program Management International, Inc.). doi:10.2204/iodp. proc.325.106.2011.

Yokoyama, Y., 2011a. Last glacial interstadials. In Hopley, D. (Ed.), Encyclopaedia of Modern Coral Reefs. New York (SpringerVerlag), 1236.

Yokoyama, Y., 2011b. Last glacial lowstand and shelf exposure. In Hopley, D. (Ed.) Encyclopaedia of Modern Coral Reefs. New York (Springer-Verlag), 1236.

Yokoyama, Y., and Esat, T.M., 2011. Global climate and sea level:
Enduring variability and rapid fluctuations over the past 150,000 years. Oceanography, 24:54-67, doi:10.5670/ oceanog.2011.27.

Yokoyama, Y., DeDeckker, P., Lambeck, K., Johnston, P., and Fifield, L.K., 2001a. Sea-level at the last glacial maximum: Evidence from northwestern Australia to constrain ice volumes for oxygen isotope stage 2. Palaeogeogr. Palaeoclim. Palaeoecol., 165:281-297, doi:10.1016/S0031-0182(00)00164-4.

Yokoyama, Y., Esat, T.M., Lambeck, K., and Fifield, L.K., 2000a. Last ice age millennial scale climate changes recorded in Huon Peninsula corals. Radiocarbon, 42:383-401.

Yokoyama, Y., Lambeck, K., DeDeckker, P., Johnston, P., and Fifield, L.K., 2000b. Timing of the Last Glacial Maximum from observed sea-level minima. Nature, 406:713-716, doi:10.1038/35021035.

Yokoyama, Y., Purcell, A., Lambeck, K., and Johnston, P., 2001 b. Shore-line reconstruction around Australia during the Last Glacial Maximum and Late Glacial Stage. Quat. Int., 83-85:9-18, doi:10.1016/S1040-6182(01)00028-3.

Yokoyama, Y., Purcell, A., Marshall, J.F., and Lambeck, K., 2006. Sealevel during the early deglaciation period in the Great Barrier Reef, Australia. Global Planet. Change, 53:147-153, doi:10.1016/j.gloplacha.2006.01.014.

\section{Authors}

Yusuke Yokoyama, Atmosphere and Ocean Research Institute, University of Tokyo, 5-1-5 Kashiwanoha, Kashiwa, Chiba 277-8564 Japan, e-mail: yokoyama@aori.u-tokyo.ac.jp.

Jody M. Webster, Geocoastal Reseach Group, School of Geosciences, The University of Sydney, Sydney, NSW 2006, Australia.

Carol Cotterill, British Geological Survey, Murchison House, Edinburgh, Scotland, EH9 3LA, U.K.

Juan Carlos Braga, Departamento de Estratigrafia y Paleontologia, Facultad de Ciencias, Universidad de Granada, Campus Fuentenueva, 18002 Granada, Spain.

Luigi Jovane, Geology Department, Western Washington University, 516 High Street, MS 908, Bellingham, WA 98225, U.S.A.

Heath Mills, Department of Oceanography, Texas A\&M University, 716A Eller, O\&M Building, College Station, TX 77843, U.S.A.

Sally Morgan, University of Leicester, Department of Geology, University Road, Leicester, LE1 7RH, U.K.

Atsushi Suzuki, Geological Survey of Japan, National Institute of Advanced Industrial Science and Technology (AIST), AIST Tsukuba Central 7, 1-1-1 Higashi, Tsukuba, Ibaraki 305-8567, Japan.

and the IODP Expedition 325 Scientists 